\title{
Evaluating the Variability in Lycopene and Agronomic Characteristics of Different Tomato (Lycopersicon esculentum Mill) Genotypes
}

\author{
*EBOIGBE, L; EDEMEVUGHE, VE \\ Department of Plant Biology, Faculty of Life Sciences, University of Benin, Benin City, Edostate, Nigeria \\ *Corresponding Author Email: lugard.eboigbe@uniben.edu
}

\begin{abstract}
S: The study was aimed at generating data in breeding for tomato varieties with improved lycopene content. Different tomato genotypes were evaluated for variability in lycopene and agronomic characteristics. The lycopene content obtained ranged from $0.024 \pm 0.004 \mathrm{mg} / \mathrm{g}$ to $0.190 \pm 0.008 \mathrm{mg} / \mathrm{g}$. LOO170 recorded the highest lycopene while NGRM10001 recorded the lowest lycopene. Lycopene in all tomato genotypes evaluated showed a coefficient of variation of $55.10 \%$. This indicated variability in the lycopene content of tomato varieties. Traits such as fruit weight, number of fruits per plant and growth rate also showed high estimate of coefficient of variation thus suggesting a positive correlation with lycopene content. High coefficient of variation in these traits thus serves as indices for selection in tomato breeding programme.
\end{abstract}

\section{DOI: https://dx.doi.org/10.4314/jasem.v22i11.11}

Copyright: Copyright $\odot 2018$ Eboigbe and Edemevughe. This is an open access article distributed under the Creative Commons Attribution License (CCL), which permits unrestricted use, distribution, and reproduction in any medium, provided the original work is properly cited.

Dates: Received: 17 October 2018; Revised: 13 November 2018; Accepted 22 November 2018

Keywords: Lycopene, Tomato genotypes, variability, agronomic trait

Tomato (Lycopersiconesculentum Mill) is one of the world's major traded vegetable. It is very important as a source of vitamin A and C, minerals and carotenoids such as lycopene. According to Ahmad and Sharma (2011), tomato is regarded as a protective food with several nutritive value traits especially antioxidant compounds which are used in several commercial therapeutic formulation. Recent studies indicate that lycopene (carotenoid that gives ripe tomato its bright red color), is very effective natural antioxidant and quencher of free radicals (Mascio, Kaiser and Sies 1989). The ability of lycopene to act as a potent antioxidant is thought to be responsible for protecting cells against oxidative damage and thereby decreasing the risks of diseases such as nervous system problems, heart diseases, skin diseases (induced by ultraviolet light), cancer and obesity (Ibitoye et al. 2009; Giovannucci 2002; Adewuyi and Ademoyegun 2008 and Loco 2011). Lycopene content of tomato typically ranges from 7 to $13 \mathrm{mg} / 100 \mathrm{~g}$ depending on variety, geographical location, technique of cultivation, climatic conditions and degree of ripeness of the fruit (Schierle et al. 1997).

The above value may have been deduced from the evaluations that have been carried out thus far. Rao and Agarwal (1998) reported lycopene in fresh tomatoes to range from $2.5-20 \mathrm{mg} / 100 \mathrm{~g}$. While Garcia and Barrett (2006) reported a lycopene range of 5.5 to $18.1 \mathrm{mg} / 100 \mathrm{~g}$ in nine tomato genotypes evaluated.
More recently, Ibitoye et al. (2009) reported a lower range of 7.25 to $14.73 \mathrm{mg} / 100$ in nine cultivated tomato germplasms evaluated for their lycopene content. Ahmad and Sharma (2011) stated that genetic variability is essentially the first step in breeding for improvement.It therefore means that the varied lycopene content in tomato is directly highlighting the possibility of higher yield, hence we decided in this research work, to screen for genotypes with lycopene yield higher than those obtained from previous evaluation. Also considering the potential health benefits of lycopenes, it will be worthwhile to seek genotypes that serve as a high reservoir of lycopene for further breeding program. Lycopene levels in plants have been observed to be directly related to ripeness and increasing $\mathrm{pH}$ (Sandeiet al. 2003). As a result, we also decided to correlate the lycopene content with some selected agronomic traits.

A lot of tomato improvement has been achieved via the introgression of new valuable genes into the tomato gene pool (Passam et al. 2007). Presently, the focus in tomato breeding is on nutritional quality (Bai and Lindhout 2007; Atanassova 2003; Shimelis and Laing 2012.). This nutritional quality has stirred up a global effort in developing tomato cultivars rich in lycopene, processing traits, high yielding and quality fruits. In order to the meet this goal, we decided in addition to evaluating for lycopene content to also include some agronomic traits that could be used in 
composite breeding. Here we report on the variation in lycopene content and its correlation with some agronomic traits as our first step in pursuing the above stated mandate.

\section{MATERIALS AND METHODS}

Plant Materials: The following germplasm were collected from the National Centre for Genetic Resource and Biotechnology (NACGRAB); NGB01255, NGB01232, NGHAA/SEP/09037, L00169, NG/AA/SEP/09/053, NGMR09005, NGMR/MAY09/005, L00170, NGSA10002 and NGRM10001. LOCAL X1 and LOCAL X2 were collected from farmers at Igbodo, Delta State.

Study area: This work was carried out in the Botanical garden of the Department of Plant Biology and Biotechnology, Faculty of Life Sciences, University of Benin, Benin City, Edo State, Nigeria. The Spectrophotometry and other laboratory work were carried out in the same Department as above.

Experimental Design and Field management: After the nursery, the transplanted tomato seedlings were seeded on the prepared soil using a randomized complete block design in three replicates. The experimental plot contained 25 plants arranged in five rows spaced $40 \mathrm{~cm}$ apart with $1 \mathrm{~m}$ spacing between and within each plot. The total field area measured $9.4 \times 5.0$ $\mathrm{m}$, the varieties were taken as treatments. The normal cultural practice such as weeding, application of manure and irrigation during the period of very low rainfall was carried out regularly.

Agronomic Traits evaluation: Preliminary evaluation were carried out on the following traits; Number of fruits per plant at first flush, Fruit size, Fruit fresh weight, Fruit $\mathrm{pH}$.

Determination of number of fruits per plant at first flush: The number of ripe fruits harvested from each plant at first flush was recorded as the number of fruits per plant.

Determination of fruit size: The transverse section of the fruits of each genotype was placed on a graph paper. The mark made on the paper was measured to give the fruit diameter.

Determination of fruit fresh weight: The fresh weight of the fruits for different genotypes was taken using an electronic weighing balance.

Determination of fruit $\mathrm{pH}$ : The pulp from the fruits of each tomato genotype was placed in a bottle. The electrode of a standardized $\mathrm{pH}$ meter was dipped into each of the bottles and the $\mathrm{pH}$ reading was taken when a steady stage was reached.

Lycopene Estimation: The lycopene content of the fruits were analyzed spectrophotometrically at a wavelength of $503 \mathrm{~nm}$. The lycopene of the tomato fruits were extracted using a mixed solvent of hexane, ethanol and acetone in a 2:1:1 ratio as described by Ibitoye et al. (2009). Three readings were taken for each accession representing fruits of different flushes. The lycopene values were expressed in $\mathrm{mg} / \mathrm{g}$ of tomato fruit.

\section{RESULTS AND DISCUSSION}

Agronomic Parameters: Among the number of fruits produced by each tomato genotypes at first flush, LOO169 recorded the highest number of fruits $(10.67 \pm 1.86)$ representing the highest yield. However this genotype had the lowest fruit weight and size (Table1). The highest fruit weight was recorded from NGB0155 with fruit weight and size of $86.57 \pm 3.32 \mathrm{~g}$ and5.04 \pm 0.05 respectively. The fruit $\mathrm{pH}$ recorded in all the tomato genotypes range 3.60-4.57 indicating that tomato is purely acidic. The lowest $\mathrm{pH}$ of 3.60 was recorded fromNGRM10001.

Lycopene Content: In this project the lycopene trait showed a high coefficient of variation (55.10\%). Among the tomato genotype, LOO170 recorded the highest lycopene content of $0.190 \pm 0.008 \mathrm{mg} / \mathrm{g}$ followed by GAASEP09053 and NGMRO9005 (table2). The lowest lycopene content was recorded for GRM10001 and LOO169 with a mean value of $0.024 \pm 0.004 \mathrm{mg} / \mathrm{g}$ and $0.030 \pm 0.013 \mathrm{mg} / \mathrm{g}$ respectively.

Correlation of Lycopene with Agronomic traits: Evaluation of the different tomato genotypes showed the relationship between some agronomic traits and lycopene content in the fruit of the tomato genotypes studied. Fruit characteristics such as fruit weight and size varied among the tomato genotypes. LOO169 and NGRM1001 recorded the lowest fruit weight and lycopene content. While NGB01255 genotype had the highest fruit weight and size but low lycopene content. However, LOO170 showed high fruit weight and high lycopene content. Generally, the fruit weight varied along with the lycopene content

The lycopene content in the fruits of twelve (12) tomato genotypes were analyzed. Based on the analysis, the lycopene content ranged from 0.024 to $0.190 \mathrm{mg} / \mathrm{g}$ (table2). The lycopene in the fruit of LOO170 was found to be high compared to previously reported values. Ahmad and Sharma (2011) reported a lower range of $1.98-4.62 \mathrm{mg} / 100 \mathrm{~g}$ in fresh tomato. Dufera (2013) also reported a lower range of 0.97 - 
$3.29 \mathrm{mg} / 100 \mathrm{~g}$. Brandt et al. (2003) and Ibitoye et al. (2009) reported a comparable lycopene range of 6$16 \mathrm{mg} / 100 \mathrm{~g}$ and $7.02-14.73 \mathrm{mg} / 100 \mathrm{~g}$ respectively. The range of the lycopene evaluation in this work in accordance with other reports signify a high variation in lycopene content in tomato varieties grown in different regions of the world. This is implicated by the high coefficient of variation $(55.10 \%)$ obtained in this work. The high coefficient of variation could serve as indices for selection in tomato breeding. The difference in lycopene recorded in fruits of tomato genotypes could be as a result of responses to different environmental conditions. Schierle et al. (1997) reported that the lycopene content of tomato typically ranges from 7 to $13 \mathrm{mg} / 100 \mathrm{~g}$ depending on variety, geographical location, technique of cultivation and climatic condition.

Table 1: Selected agronomic traits; Fruit Characteristics of Tomato genotypes

\begin{tabular}{lllll}
\hline \multicolumn{1}{c}{ Accession Number } & Fruit Weight $(\mathbf{g})$ & Fruit Size $(\mathbf{c m})$ & Fruit $\mathbf{p H}$ & No. of Fruits per Plant \\
\hline Local X $_{1}$ & $28.68 \pm 4.12 c d$ & $3.59 \pm 0.14 f$ & 3.90 & $8.50 \pm 1.50 a b$ \\
Local X & $26.27 \pm 0.66 b c d$ & $2.15 \pm 0.03 b$ & 4.00 & $3.50 \pm 0.50 a$ \\
NGBO 1255 & $86.57 \pm 3.32 e$ & $5.04 \pm 0.05 g$ & 4.13 & $3.00 \pm 1.00 a$ \\
NGBO 1232 & $17.89 \pm 0.90 b$ & $3.28 \pm 0.09 d e f$ & 4.15 & $7.33 \pm 1.09 b$ \\
NGHAA/SEP09037 & $29.54 \pm 0.62 c d$ & $3.61 \pm 0.06 f$ & 4.05 & $4.00 \pm 1.08 a b$ \\
LOO 169 & $1.42 \pm 0.13 a$ & $0.86 \pm 0.14 a$ & 4.00 & $10.67 \pm 1.86 b$ \\
NGAA/SEP09053 & $19.15 \pm 0.70 b c$ & $3.15 \pm 0.12 d e$ & 4.57 & $7.50 \pm 2.50 a b$ \\
NGMR 09005 & $31.53 \pm 10.39 d$ & $3.45 \pm 0.21 e f$ & 4.34 & $3.33 \pm 0.33 a$ \\
NGMRMAY 09005 & $17.30 \pm 1.59 b$ & $3.05 \pm 0.10 c d$ & 4.60 & $5.50 \pm 3.30 a b$ \\
LOO 170 & $27.85 \pm 0.94 b c d$ & $3.60 \pm 0.09 f$ & 4.00 & $3.33 \pm 0.88 a$ \\
NGSA 10002 & $6.23 \pm 0.16 a$ & $2.45 \pm 0.02 b$ & 3.90 & $10.50 \pm 1.46 b$ \\
NGRM 10001 & $0.43 \pm 0.06 a$ & $0.92 \pm 0.16 a$ & 3.60 & $10.33 \pm 1.45 b$ \\
Means \pm S. E. & $\mathbf{2 4 . 4 1} \pm \mathbf{6 . 4 7}$ & $\mathbf{2 . 9 3} \pm \mathbf{0 . 3 4}$ & $\mathbf{4 . 1 0} \pm \mathbf{0 . 6 8}$ & $\mathbf{6 . 4 6} \pm \mathbf{0 . 8 8}$ \\
C. V. (\%) & $\mathbf{9 1 . 8 7}$ & $\mathbf{1 1 . 6 7}$ & $\mathbf{1 . 9 8}$ & $\mathbf{4 7 . 2 3}$ \\
\hline \multicolumn{4}{c}{ Values with same subscripts (letters) are not significantly different at 0.05 levels of significance. }
\end{tabular}

L00170 recorded the highest lycopene content of $0.190 \pm 0.008 \mathrm{mg} / \mathrm{g}$ which is reasonably high when compared to other varieties (table2). This suggest that this variety can be used as a parent in breeding for higher lycopene especially with marketable varieties. In this work, marketable tomato varieties, LOCAL X1 and LOCAL X2 showed low lycopene content compared to some of the genotypes from NACGRAB. This highlighted the importance of a targeted breeding. In such breeding programme, identification of tomato varieties with high potential of lycopene and crossing them with varieties having other economically important traits is the first step in breeding strategies (Dufera 2013). This kind of breeding, we have also coined in this work as composite breeding.

Table 2: Fruit lycopene content of tomato genotypes

\begin{tabular}{ll}
\hline Accession Number & Fruit Lycopene Content (mg/g) \\
\hline Local X $_{1}$ & $0.067 \pm 0.002 b c d$ \\
Local X & $0.086 \pm 0.010 c d e$ \\
NGBO 1255 & $0.059 \pm 0.004 b c$ \\
NGBO 1232 & $0.083 \pm 0.005 c d e$ \\
NGHAA/SEP09037 & $0.042 \pm 0.009 a b$ \\
LOO 169 & $0.028 \pm 0.008 a$ \\
NGAA/SEP09053 & $0.097 \pm 0.022 e$ \\
NGMR 09005 & $0.096 \pm 0.003 d e$ \\
NGMRMAY 09005 & $0.091 \pm 0.010 d e$ \\
LOO 170 & $0.190 \pm 0.008 f$ \\
NGSA 10002 & $0.080 \pm 0.007$ cde \\
NGRM 10001 & $0.024 \pm 0.004 a$ \\
Means \pm S. E. & $\mathbf{0 . 0 7 9} \pm \mathbf{0 . 0 1 3}$ \\
C. V. $(\%)$ & $\mathbf{5 5 . 1 0}$ \\
\hline \multicolumn{2}{c}{ at 0.05 levels of significance. }
\end{tabular}

In search of economically important traits, we decided to evaluate some agronomic traits along with lycopene. The high coefficient of variation observed in lycopene, was also seen in growth rate, fruit weight and number of fruits per tomato plant evaluated.This suggests a correlation between lycopene and these agronomic traits. In our future work, we hope to check the segregation of lycopene gene with the aforementioned agronomic traits through molecular studies.

In conclusion, it is evident from this work that tomato varieties differ in their level of lycopene and yield. The high coefficient of variation recorded by these characters can serve as a basis for breeding and improving tomato varieties. Moreover, on the basis of the potential health benefits of lycopene, screening for tomato with high lycopene content with high fruit quality is worthwhile.

\section{REFERENCES}

Adewuyi G, O; Ademoyegun, OT (2008). Analysis of Vitamin $\mathrm{C}$ and major caroteniods in different fractions of tomato.Proceedings of International Conference on Science and Technology in Africa, 2: $65-73$

Ahmad, R D; Sharma, JP (2011). Genetic variability studies of yield and quality traits in tomato. International Journal of Plant Breeding and Genetics 5:168-174 
Atanassova, B; Shtereva, L; Baralieva, D; Georgiev, H R (2003). Study of the content variation of Compounds related to nutritive and Flavour quality in tomato (Lycopersicon esculentum Mill) Acta Horticulturae 613:327-330

Bai,Y; Lindhout, P (2007). Domestication and breeding of tomatoes. Annuals of Botany, 100:1085-1094

Brandt, S; Lugasi, A; Barna, E; Hovari J; Pek, Z and Helyes, L (2003). Effects of growing methods and conditions on the lycopene content of tomato fruits. Acta Alimentaria, 32:269-278

Dufera, JT (2013). Evaluation of agronomic performance and lycopene variations in tomato (Lycopersiconesculentum Mill.) genotypes in Mizan, Southwestern Ethiopia.World Applied Science Journal, 27:1450-1454

Garcia, E; Barrett, DM (2006). Assessing lycopene content in California processing tomatoes. Journal of Food Processing and Preservation 30:56-70

Giovannucci, J (2002). A review of epidemiologic studies of tomatoes. Lycopene and Prostate Cancer 227:852-859

Ibitoye, DO; Akin-Idowu, PE and Ademoyegun, OT (2009).Agronomic and lycopene evaluation in tomato (Lycopersiconesculentum Mill) as a function of genotype.World Journal of Agricultural Sciences, 5: 1085-1094
Loco, JV (2011). Assessment of dietary intake of lycopene by the Belgian adult population. Whytsmanstraat, Brussels. 80pp

Mascio, P; Kaiser, S and Sies, H (1989). Lycopene as the most sufficient biological carotenoid singlet oxygen quencher. Archives of Biochemical Biophysics 274:532-538

Passam, HC; Karaparos, IC; Belbeli, PJ and Dimitrois, $S$ (2007). A review of recent research on tomato nutrition, breeding and post-harvest technology.The European journal of Plant Science and Biotechnology, 1:1-21

Roa, AV; Agarwal, S (1998).Bioavailability and in vivo antioxidant properties of lycopene from tomato products and their possible role in the prevention of cancer. Nutrition and cancer31: 199203

Sandei, L; Siviero, P; Zanotti, G; Cabassi, A and Leoni, C (2003).Evaluation of the Lycopene content in processing tomato cultivars claiming high pigment content. Acta Horticulturae 613: 331-331

Schierle, J; Brezel, W; Buhler, I; Fecein, N; Hess, D; Steinerk, C. and Sheup, W (1997). Content and isomeric ratio of lycopene in food and human blood plasma. Food Chemistry 59: 459-465

Shimelis, H; Laing, M. (2012). Timeline in conventional crop improvement: pre-breeding and breeding procedures. Australia Journal of Crop Science 6:1542-1549 